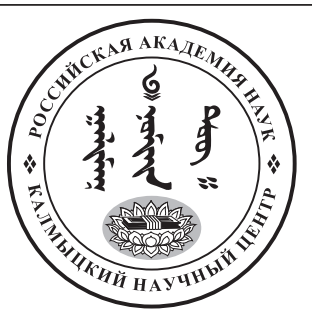

Published in the Russian Federation

Oriental Studies (Previous Name: Bulletin of the Kalmyk Institute

for Humanities of the Russian Academy of Sciences)

Has been issued as a journal since 2008

ISSN: 2619-0990; E-ISSN: 2619-1008

Vol. 13 , Is. 3 , pp. $546-559,2020$

DOI: $10.22162 / 2619-0990-2020-49-3-546-559$

Journal homepage: https://kigiran.elpub.ru

УДК 94(517)

DOI: 10.22162/2619-0990-2020-49-3-546-559

\title{
Сотрудничество Калмыкии и Монголии в 20-х годах XX в.
}

\author{
Кеемя Владимировна Орлова
}

${ }^{1}$ Институт востоковедения РАН (д. 12, ул. Рождественка, 107031 Москва, Российская Федерация) доктор исторических наук, кандидат филологических наук, ведущий научный сотрудник

D) 0000-0003-4951-0063.E-mail: orlovnk@mail.ru

\author{
(C) КалмНЦ РАН, 2020 \\ (C) Орлова К. В., 2020
}

Аннотация. Введение. Сотрудничество Калмыкии и Монголии в 1920-х гг. остается недостаточно изученной темой как в калмыцкой, так и в монгольской историографии. Со времени прихода калмыков в Россию в XVII в. взаимоотношения с монголами в основном были эпизодическими, когда калмыки с паломническими целями через Монголию добирались в Тибет. Особо тесные связи начинают развиваться в 1920-е гг. Этот период для обоих народов оказался чрезвычайно сложным и в определенной мере трагическим: на территории Калмыцкой степи шла Гражданская война, Внешняя Монголия находилась в «котле» социальных преобразований, когда в прямом смысле решалась судьба страны, ее независимость. В этих непростых условиях калмыки прибыли в Монголию в качестве военных инструкторов для формирования и обучения воинских частей монгольской народно-революционной армии. Монголия оказала существенную гуманитарную помощь голодающим жителям Калмыкии. Более того, монгольское правительство инициировало переезд голодающих калмыков в страну с предоставлением серьезных субсидий. Военные и гуманитарные аспекты освещены в публикациях калмыцких и монгольских исследователей. Цель статьи - дать дополнительные сведения по упомянутым и другим областям сотрудничества Калмыкии и Монголии в указанный период по опубликованным источникам, архивным материалам и научной литературе, в том числе по документам из Центрального архива ФСБ России и сборника документов «Российско-монгольское военное сотрудничество». Материальы. В статье использованы архивные документы, научная литература, архивные документы из Центрального архива ФСБ России, сборника документов «Российско-монгольское военное сотрудничество». Результаты. Появление в монгольской армии калмыков не случайно, советское руководство прекрасно понимало, что им, в недавнем прошлом кочевникам, легче будет адаптироваться среди соплеменников. Их главная задача состояла в оказании помощи командному составу монгольской народно-революционной армии, формировании воинских частей. Монголия, в свою очередь, внесла посильную помощь 
в период голода в Калмыкии в 1921 г. В январе 1923 г. монгольское правительство выступило с инициативой переселения голодающих калмыков в Монголию. Развитие двусторонних взаимоотношений показало, что при выстраивании отношений советское руководство, прежде всего, исходило из родственных связей между народами, языковой и культурной общности. Немаловажную роль сыграла религиозная идентичность.

Ключевые слова. Калмыкия, Монголия, сотрудничество, 20-е годы XX в.

Для цитирования: Орлова К. В. Сотрудничество Калмыкии и Монголии в 20-х годах XX в. // Oriental Studies. 2020. T. 13. № 3. C. 546-559. DOI: 10.22162/2619-0990-2020-49-3-546-559

UDC 94(517)

DOI: $10.22162 / 2619-0990-2020-49-3-546-559$

\title{
Kalmykia - Mongolia Cooperation: 1920s
}

\author{
Keemya V. Orlova ${ }^{1}$
}

${ }^{1}$ Institute of Oriental Studies of the RAS (12, Rozhdestvenka St., Moscow 107031, Russian Federation) Dr. Sc. (History), Cand. Sc. (Philology), Leading Research Associate iD 0000-0003-4951-0063. E-mail: orlovnk@mail.ru

(C) KalmSC RAS, 2020

(C) Orlova K. V., 2020

\begin{abstract}
Introduction. The issue of Kalmykia-Mongolia cooperation in the 1920s still remains understudied both in Kalmyk and Mongolian historiography. Ever since the Kalmyks migrated to Russia-controlled territories, relations with Mongolia became irregular enough and were largely reduced to pilgrimage contacts en route to Tibet. But the 1920s witnessed an intensification therein. The period proved extremely harsh and definitely dramatic to both the nations: Kalmyk Steppe became an operational theater of the Russian Civil War, and Outer Mongolia sank into the 'pot' of social transformations and struggle for independence. And it is in those tough times that Kalmyks arrived in Mongolia as military instructors to arrange the formation and training of troop units for the Mongolian People's Revolutionary Army. On the other hand, Mongolia delivered humanitarian aid to Kalmykia during the famine. Moreover, the Mongolian Government initiated a resettlement of starving Kalmyks to the country, with significant allowances to be funded. The military and humanitarian aspects have been examined by a number of Kalmyk and Mongolian researchers. Goals. The paper aims to provide additional data on the mentioned and other realms of cooperation during the period under consideration. Materials. The study analyzes new sources, archival materials, and scholarly works, including documents stored at the Central Archive of Russia's Federal Security Service and ones introduced in Russia-Mongolia Military Cooperation. Results. The attachment of Kalmyks officers to Mongolian military units attests to that the Soviet Government recognized the exnomads should aptly adapt themselves to familiar conditions and cultural environment. Their primary objective was to help commanders of the Mongolian People's Revolutionary Army create efficient military forces. And Mongolia did its best to support Kalmykia during the famine of 1921. In January of 1923, the Government of Mongolia initiated a resettlement of starving Kalmyks. Chronicles of relations show the key landmarks for the Soviet Government therein were ethnogenetic ties between the populations, linguistic and cultural affinities. Religious identity also proved an important unifying element.
\end{abstract}

Keywords: Kalmykia, Mongolia, cooperation, 1920s

For citation: Orlova K. V. Kalmykia-Mongolia Cooperation: 1920s. Oriental Studies. 2020. Vol. 13(3): 546-559. (In Russ.). DOI: 10.22162/2619-0990-2020-49-3-546-559 


\section{Введение}

1920-е гг. — чрезвычайно тяжелое и драматическое время и в Калмыкии, и в Монголии. Этот период всеобъемлюще представлен в российских и монгольских публикациях, в которых на широком материале освещаются международные отношения, экономические, политические и культурные аспекты. Сотрудничество Калмыкии и Монголии этого периода до сих пор остается недостаточно изученной темой. Впервые упоминание о калмыках-инструкторах встречается в книге монгольского ученого Б. Ширендыба [Ширендыб 1971: 222].

Большинство публикаций о калмыках в Монголии в 1920-х гг. принадлежат доценту Калмыцкого государственного университета, кандидату исторических наук Ю. О. Оглаеву. Как он сам пишет, «сбор и публикацию об участниках революции в Монголии» задумал еще в юности [Оглаев 1970: 26]. В 1966 г. в газете «Советская Калмыкия» появилась его первая публикация «У истоков дружбы». Тогда же начались целенаправленные поиски и выявление документальных материалов из Центрального государственного архива Калмыцкой АССР (ЦГА КАССР, ныне Национальный архив Республики Калмыкия (НА РК)) о пребывании калмыков и их участии в событиях того периода в Монголии. Найденные архивные документы стали основой небольшой брошюры, в которой запечатлены воспоминания ветеранов-калмыков о тех годах [С интернациональной миссией 1970].

В 1973 г. в сборнике, посвященном памяти участника революционных событий в Монголии, выдающегося ученого-монголоведа и калмыковеда Церен-Дорджи Номинханова, была подробно освещена его деятельность с мая 1921 по август 1923 гг., не только как военного, но и общественного деятеля. Именно работа в этой стране пробудила его интерес к науке, после службы в Монголии он поступил в Петроградский институт живых восточных языков им. Енукидзе (с 1924 г. — Ленинградский институт живых восточных языков) [Оглаев 1973]. В 1981 г. выходит статья Ц.-Д. Номинханова о деятельности Х. Б. Канукова в Монголии [Оглаев 1981].
В том же году в журнале «Теегин герл» ('Свет в степи') публикуется статья участника событий монгольской революции М. Т. Бимбаева [Бимбаев 1981], которая охватывает период с 1921 г по 1946 гг. и во многом воспроизводит воспоминания, зафиксированные в брошюре, которую подготовил ранее Ю. О. Оглаев [С интернациональной миссией 1970].

Во втором томе фундаментального издания «История Калмыкии с древнейших времен до наших дней» (2009) лаконично излагается помощь Монголии голодающим калмыкам [История Калмыкии 2009: 322323].

В монографии Е. Н. Бадмаевой кратко освещается поддержка калмыков монголами в рамках международной гуманитарной помощи голодающим жителям Нижнего Поволжья [Бадмаева 2010: 174-176].

На основе документов из архивов Монголии Н. Наранжаргал подробно исследует вопросы помощи голодающим калмыкам и проект их переселения на историческую родину [Наранжаргал 2014: 50-56]. В другой его статье представлены новые источники о пребывании монгольской делегации в СССР [Наранжаргал 2015: 31-34].

Суммируя опубликованную литературу, отмечу, что сотрудничество между странами в 1920-е гг. рассматривается в двух аспектах - военной и гуманитарной. Цель данной статьи - дополнить сведения о некоторых аспектах сотрудничества Калмыкии и Монголии в указанный период по опубликованным источникам, архивным материалам и научной литературе, в том числе документам из сборника «Монголия в документах из архивов ФСБ России (19221936 гг.)» [Монголия в документах 2019].

Общее положение Калмыкии и Монголии в начале 1920-х гг.

Со времени прихода калмыков в Россию взаимоотношения с монголами в основном были эпизодическими, когда калмыки с паломническими целями через Монголию добирались в Тибет. Особо тесные связи развиваются в 1920-е гг. В эти годы на территории Калмыкии шла Гражданская война, большая ее часть была занята белыми, 
и на этой территории советская власть распущена, над остальной, незанятой белыми, Калмыцкой степью нависла угроза ее потерять. Именно это обстоятельство подвигло советские и партийные органы реально оценить масштабы конкретной опасности. По признанию руководства советской власти Калмыцкой степи, они «на Калмыкию мало обращали внимания, и, возможно, поэтому белогвардейцы ее так легко заняли» (цит. по: [История Калмыкии 2009: 264]).

Развернулась активная агитационная работа, выпускались листовки на калмыцком языке, активно предпринимались меры по улучшению экономического состояния, в частности, изданы постановление СНК РСФСР об устройстве земельного быта калмыков и ряд декретов и постановлений по улучшению экономического положения. В политическом отношении выходит знаменитое обращение Ленина «к братьям калмыкам» [История Калмыкии 2009: 265].

Со временем советская власть в Калмыкии была восстановлена, Гражданская война на ее территории в основном завершилась. Активную роль на заключительном этапе войны сыграли Х. Б. Кануков (комбриг), М. Д. Шапшуков, В. А. Хомутников, М. Т. Бимбаев, Т. Б. Шивидов и др. [История Калмыкии 2009: 270], которые впоследствии отправятся в Монголию.

В Монголии ситуация также была крайне сложна. По мнению известного монголоведа С. К. Рощина, первая четверть ХХ в. в Монголии, с одной стороны, «время коренных демократических преобразований, национального и государственного возрождения», с другой — «этап суровых социальных потрясений, изнурительной борьбы в обществе, ... период, послуживший, в известном смысле, основой последующего развития» [Рощин 1999: 308].

После революции 1921 г. монгольские демократы считали, что только опора на Советскую Россию и Коминтерн обеспечит национальную независимость [Батунаев 2016: 184]. Однако эта ситуация не устраивала Китай, который «настойчиво и весомо восстанавливал утраченные позиции» [История Монголии 2007: 43].

Понимая, что своими силами монголы не в состоянии отразить претензии республиканского Китая (что и случилось: «китайское военное присутствие и отказ от автономии $\left.{ }^{1} \gg\right)$, князья и высшее ламство Внешней Монголии обратились за помощью к США и Японии, однако, не получив ответ, адресовали просьбу советскому правительству через уполномоченного [Лузянин 2000: 91; Курас 2016: 181].

Летом 1920 г. в Иркутск отправилась делегация монгольских революционеров с намерением добиться автономии страны при помощи Советской России, однако эти попытки ни к чему не привели. Тем не менее, диалог завязался, и некоторые члены делегации отправились в Москву, где на заседании Политбюро ЦК РКП(б) обсуждался монгольский вопрос [История Монголии 2007: 51, 52; Наранжаргал 2015; Курас 2016: 182, 183]. «Автономизация» Монголии вновь не стала краеугольным камнем встречи, однако «образ монгольской коммунистической монархии» привлек внимание Москвы в свете продвижения мировой революции на Восток, трамплина в Маньчжурию, Тибет и Индию [Курас 2016: 183].

В феврале 1921 г. активизируется барон Унгерн, направивший свою дивизию в Ургу. Монголия провозглашает независимость, а Богдо-гэгэн возвращается к обязанностям теократического монарха страны. Но, как оказалось, не всех монголов устраивала эта ситуация. В марте 1921 г. состоялось совещание монгольских революционеров, впоследствии (1924 г.) организационно оформленное как I съезд Монгольской народной партии (МНП), на нем были выдвинуты главные задачи - «завоевание независимости страны и передача государственной власти в руки народа» [Хишигт 2011: 31]. Сформированное Временное правительство Монголии заявило о готовности принять на себя руководство страной: «освобождение от китайской власти, очищение от белогвардейских, хунхузских и других вооруженных сил, сношение с соседними дружественными монгольскому народу державами и созыв учредительного съезда представителей монгольского народа для организации постоянного правительства и выработки основных законов страны» [Российско-мон-

${ }^{1}$ Согласно русско-китайской Декларации от 5 ноября 1913 г., «Внешняя Монголия была признана автономной, ее территория частью Китая, а правительство Китая - сюзереном автономной Внешней Монголии» [История Монголии 2007: 40]. 
гольское 2019: 136]. Так случилось двоевластие в стране: в Урге находилось правительство Богдо-гэгэна при поддержке Унгерна, а на севере - народное правительство под патронажем России. Унгерну (монголы «разочаровались в Унгерне насилиями» [Российско-монгольское 2019: 136]) не оставалось иного выхода, кроме как двинуть свою дивизию на север. В письме своему представителю в Северном Китае К. Грегори Унгерн сообщает: «Я начинаю движение на север и на днях открою военные действия против большевиков. ... И когда я увижу планомерность поднятого в России движения, я перенесу свои действия на Монголию» [Российско-монгольское 2019: 160].

Одним из поводов выдвинуться послужило известие от атамана Семенова «принять участие в широкомасштабной операции белых, при поддержке Японии, против красных ... с выходом на берег Байкала и захватом Верхнеудинска» [Курас 2016: 185].

Опасность продолжения войны уже на российской территории вынудила советское правительство начать ввод части своих войск в Монголию, исходя их двух задач: военной - для разгрома дивизии Унгерна и политической — «помочь молодым монгольским революционерам овладеть ситуацией в стране» [Рощин 1999: 21].

\section{Калмыцкие военные в Монголии в период революции 1921 г.}

Координация деятельности России и Коминтерна в Монголии осуществлялась под руководством члена Реввоенсовета 5-й армии и уполномоченного НКИД по Сибири и Монголии Б. З. Шумяцкого. Главную задачу он видел, помимо прочих, в укреплении народной власти и правительства на всей территории страны, приобретении «в лице Монголии союзника» (цит. по: [Рощин 1999: 37]). Надо признать, что состав членов народной партии был довольно неоднороден; неопытность, отсутствие знаний политической работы сказывались на ежедневной работе. Поэтому возникла еще одна проблема - привлечение опытных и квалифицированных кадров. Современные исследователи периода 1920 -х гг. высоко оценивают заслуги бурят и калмыков в монгольской истории: роль бурят сказалась в развитии культуры и образования, а калмыков - в военной помощи. Специа- листы из Бурятии оказались «...полезными, можно сказать незаменимыми... они были тесно связаны с Монголией, имели там обширные связи. В 1920-1921 гг. в Монголию приехала группа бурятских работников, хорошо разбиравшихся в обстановке, неплохо подготовленных, образованных. Некоторые из них приняли монгольское гражданство, стали членами МНП, другие остались российскими подданными. ...занимали те или иные ответственные посты» [Рощин 1999: 38]. Эти слова в полной мере можно отнести и к калмыкам: знание языка, общность традиций, культуры ${ }^{2}$ с монголами сыграли определяющую роль. Вероятно, военные навыки калмыков (быстрота передвижения, маневренность и внезапность нападений калмыцкой конницы) оставались в фокусе внимания российских властей. Со времени прихода в Россию в начале XVII в. калмыки действительно стали реальной военной силой в решении военно-политических проблем. В период вплоть до откочевки большей части калмыков на историческую родину в 1771 г. ни одна военная операция России не обходилась без участия калмыцких воинов, и калмыки показали себя надежными союзниками.

В архивных документах калмыков в Монголии именовали торгутами. И это не случайно. На основании анализа грамот (в переводе с тибетского и ойратского языков), дарованных Далай-ламами калмыцким ханам или калмыцким паломникам, Э. П. Бакаева делает обоснованный вывод «о наименовании в тибетской традиции того времени калмыков ,народом торгутов“"», соответственно «Торгутским» именовалось и Калмыцкое ханство [Бакаева 2019: 904] (перевод грамот см.: [Бакаева 2019: 902-907, 910-911, 912-915]) - хотя в русских документах XVII в. ойратов, мигрировавших на территорию России, именовали калмыками. Важным фактором, объясняющим использование термина «торгут» по отношению ко всем калмыкам в XVII - начале XVIII вв., представляется приход на территорию России в XVII в. «наиболее крупной ....по чис-

${ }^{2}$ По воспоминаниям М. Т. Бимбаева, на первой встрече с Д. Сухэ-Батором по прибытии калмыков в Маймачен «каждая сторона разговаривала на родном языке и ко всеобщей радости без труда понимали друг друга» [Бимбаев 1981: 61]. 
ленности этнической группы ойратов ${ }^{3}$, ставшей основой калмыцкого народа, к которой принадлежали и представители правящей династии ханов (торгутов из родов кереитов)» [Бакаева 2019: 891]. С кавказскими походами калмыков в XVII-XVIII вв. связано наличие в кабардинско-черкесско-русском словаре слова «тургъут» (в переводе 'къалмыкъ'), в языке адыгов «до настоящего времени в качестве термина, обозначающего всех калмыков, сохраняется этноним „торгут“» [Бакаева 2019: 896].

В начале XX в. в грамоте Далайламы XIII, любезно дарованной прибывшему с паломническими целями малодербетовскому монаху Агвану Санджи, обозначен адресат «всем, живущим во владении Торгутского ханства» [Бакаева 2019: 912-916]. Еще в одной грамоте Далай-ламы XIII, сохранившейся до настоящего времени, также содержится обращение тибетского иерарха к жителям Торгутского ханства [Бакаева 2019: 916-921].

Итак, на основании тщательно проведенного анализа архивных документов Э. П. Бакаева убедительно показала, что в буддийской традиции «этноним ,торгут“ связывался с калмыцким народом», который в русских документах назывался калмыками [Бакаева 2019: 891-925]. Именно поэтому в монгольских документах калмыков называют торгутами. Так, находясь в Монголии, Х. Б. Кануков подписывался: «сотрудник в монгольской народной армии донской калмык-торгут» [НА РК. Ф. Р-137. Оп. 1. Д. 4. Л. 22].

Появление в монгольской армии калмыков не случайно, советское руководство прекрасно понимало, что им, в прошлом кочевникам, легче будет адаптироваться среди соплеменников. Их главная задача состояла в оказании помощи командному составу монгольской народно-революционной армии (МНРА), формировании воинских частей, обучении монгольских цириков ${ }^{4}$. В свою очередь и для инструкторов были

${ }^{3}$ В Россию прикочевали примерно 50 тыс. семей торгутов, 4 тыс. семей дербетов, 4 тыс. семей хошутов и 2 тыс. семей цоросов (цит. по: [Бакаева 2019: 893]).

${ }^{4}$ По свидетельству М. Т. Бимбаева, с 1921 по 1934 гг. в Монголии калмыки работали не только военными специалистами, но и врачами, учителями и др. [Бимбаев 1981: 62]. выработаны предписания: «а) там, где имеется подготовленный командир-монгол, могущий работать без инструктора, - ставить командиром монгола одного, б) необходимо, чтобы командир-монгол прошел практический курс знаний комсостава, в) там, где во главе стоит инструктор - инструктор является командиром со всей полнотой власти, а монгол его помощником, г) необходимо к инструкторскому составу применять дисциплинарный устав нарревармии (народно-революционная армия. $-K$. O.) неукоснительно как в боевой обстановке, д) наличный состав инструкторов проверить и всех неподходящих удалить» [Российско-монгольское 2019: 201].

По сообщению начальника Прибайкальского губернского отдела ГПУ Клиндера и уполномоченного по ИНО работе Игнатьева, бойцы монгольской армии «мало подготовлены и потому должностям не соответствуют», обмундирование, снаряжение и лошадей получали из своих хошунов, откуда были родом. Дисциплина, знание военного дела и боеспособность не выдерживали никакой критики, не было и определенного срока службы в армии, учета оружия: «все территориальные части не носят и тени воинских частей, не говоря уже о боеспособности» [Монголия в документах 2019: 18]. Как отмечали Клиндер и Игнатьев, по прибытии в воинские части воины-монголы проживали по-прежнему «в монгольских юртах, оборваны, разуты» [Монголия в документах 2019: 18], к тому же не был налажен их учет в связи со свободным их перемещением. Реорганизация Монгольской армии по типу европейской планировалась только к 1923 г. [Монголия в документах 2019: 18]. Такая же характеристика монгольской армии приводится и в сборнике документов «Российско-монгольское военное сотрудничество»: «совершенно не обученные или плохо обученные народоармейцы, вооружение в чрезвычайно плохом состоянии, командный состав отсутствовал, инструктора безграмотны, комиссары тоже» [Российско-монгольское 2019: 258]. С такой армией и воинами калмыкам-инструкторам предстояло работать. Монгольское правительство со своей стороны гарантировало инструкторам «выдачу

${ }^{5}$ Документ датирован 1923 г., к приезду калмыков в 1921 г. положение монгольской армии было таким же, если не хуже. 
обеспечения, достаточного для исполнения службы и не наносящего урона их материальному благополучию» [Российско-монгольское 2019: 264].

Первая группа калмыков (в Монголии все они имели псевдонимы), командиров и младших командиров 108-го Калмыцкого кавалерийского полка, во главе с Х. Б. Кануковым (в Монголии работал под именем Итрах Вокунаев ${ }^{6}$, еще один псевдоним Канукова - Балданцэрэн - приводит Н. Наранжаргал [Наранжаргал 2014: 52]), прибыла в Монголию в 1921 г., возраст ее участников варьировался от 21 года (Н. Т. Манджиев) до 40 лет (Х. Б. Кануков) [НА РК. Ф. Р-137. Оп. 1. Д. 4. Л. 200-201].

Эту группу военных специалистов (18 человек) распределили по частям МНРА в составе сводного Экспедиционного корпуса советских войск под командованием К. А. Неймана [Российско-монгольское 2019: 169]. Через штаб командующего войсками Сибири и Дальневосточный секретариат Коминтерна их перебросили в Монголию. По прибытии в Маймачен (ныне Алтан-Булак) калмыков принял главнокомандующий Монгольской армии Д. Сухэ-Батор. В начале июня 1921 г. в окрестностях Маймачена монгольская армия совместно с 36-м артдивизионом Экспедиционного корпуса уже приняла первый бой [Российско-монгольское 2019: 146; Бимбаев 1981: 61]. А в конце июня войска ${ }^{7}$ двинулись на Ургу, которая была освобождена в июле [Российско-монгольское 2019: 182, 186], в результате состоялась «передача власти старым монголправительством [монгольское правительство. $-K$. O.] новому нарревправительству [народно-революционное правительство. - $K$. O.]» [Российско-монгольское 2019: 186].

Первым военным комендантом столицы Монголии стал Х. Б. Кануков ${ }^{8}$, его помощ-

\footnotetext{
${ }^{6}$ В документах и научной литературе также встречается написание Вакунаев.

7 По сведениям акад. АН МНР Б. Ширендыба, в состав Экспедиционного корпуса советских войск входили две бригады 35-й дивизии, 5-я кавалерийская дивизия и отдельная Сретенская кавалерийская бригада [Ширендыб 1971: 255].

8 Далее его военная карьера продолжилась в качестве советника разведывательного отдела штаба монгольской армии, инструктора первой регулярной монгольской кавалерийской бригады.
}

ником - Буур (Борис) Учурович Юнзуков (в Монголии стал называться Церен-Дорджи Номинхановым), начальником ургинской тюрьмы - Ц.-М. Очиров [НА РК. Ф. 3.137. Оп. 1. Д. 4. Л. 12]. Работа коменданта заключалась в выявлении контрреволюционеров, налаживании быта, а также охране правительственных и государственных учреждений столицы, регистрации граждан и постановке на учет иностранцев, помощи в расквартировании советских и монгольских военных, прибывавших в Ургу, и др. После отъезда Х. Б. Канукова в Кобдо по решению монгольского правительства военную комендатуру Урги возглавил Ц.-Д. Номинханов [Оглаев 1973: 33].

В августе 1921 г. в Урге была создана высшая военная школа (по документам из Центрального архива ФСБ России - училище [Монголия в документах 2019: 480]) с четырьмя отделениями: пехотным, кавалерийским, артиллерийским и инженерным [Российско-монгольское 2019: 204]. Учеба с учетом местных условий проводилась по программе обучения младшего командирского состава Красной Армии. Руководителями учебного процесса стали советники П. М. Толпыгин и И. Вокунаев (Х. Б. Кануков). Уже с 1926-1927 гг. начался выпуск «командиров, артиллеристов, пулеметчиков, связистов, хозяйственников, политработников со средним военным образованием» [Монголия в документах 2019: 480].

Однако предстояла дальнейшая борьба по окончательному освобождению страны (западной части Монголии), и монгольское правительство обратилось с просьбой к советскому правительству отложить вывод войск [Российско-монгольское 2019: 185, $187,231,232]$. Вторую группу командиров и красноармейцев (50 человек) во главе с М. Лиджиевым и третью группу (42 человека) под командованием М. Шапшукова объединили в единый Отдельный калмыцкий эскадрон и отправили в Монголию в декабре 1921 г. Они выполняли те же задачи, обучая монгольских цириков [С интернациональной миссией 1970]. В общей сложности эти группы калмыков находились в стране от трех до пяти лет. Монголия высоко оценила боевые заслуги калмыков, наградив некоторых орденом Красного Знамени, «торгута Вахунаева» (т. е. Вакунаева (Х. Б. Канукова). - К. О.), помимо ордена, 
еще 500-ми тугриками [Бимбаев 1981: 62; Российско-монгольское 2019: 245]. Случались и перегибы в работе советских инструкторов и военных специалистов: так, в письме поверенного в делах РСФСР в Монголии В. И. Юдина заместителю начальника отдела пограничной охраны Ф. И. Бонову сообщалось о расправах над гражданами и солдатами ${ }^{9}$, к которым привлекались и калмыки [Монголия в документах 2019: 36].

Дальнейшая военная служба Х. Б. Канукова продолжилась в Западной Монголии, в апреле 1922 г. его направили помощником уполномоченного монгольского правительства в Кобдоском округе с одновременным исполнением обязанностей начальника разведки и политотделов округа. В Кобдо с Х. Б. Кануковым находился инструктор кавалерийского полка калмык Кульцмеев ${ }^{10}$ («происходит из торгоутцев (член партии)») [Монголия в документах 2019: 89]).

С 1 июля того же года Х. Б. Кануков начальник штаба Кобдоского военного округа и его военный руководитель. В округе он организовал 1-й и 2-й кавалерийские полки: один состоял исключительно из халха-монголов, другой - из монгольских («местных» $\left.{ }^{11}\right)$ дербетов. Обучение цириков проходило через переводчика, их обучали строевой подготовке, ежедневно велись политзанятия. Х. Б. Кануков составил программу обучения цириков, организовал полковую школу для младшего комсостава, в котором велись занятия как общеобразовательного уровня, так и, естественно, «по-

${ }^{9}$ Согласно документу, «монголы с монголами же расправляются, а казнить русских представляют же русским же - тов. Шлихту, нашим торгутам» [Монголия в документах 2019: 36]. (Шлихт являлся следователем Государственной внутренней охраны (ГВО) - см.: [Монголия в документах 2019: 36]).

${ }^{10}$ В списке калмыков, работавших в 1923 г. в различных войсковых частях и военных организациях Монголии, значится Цецен Кюльценгеев. Возможно, речь идет о нем [С интернациональной миссией 1970: 139].

11 В Кобдоском крае с XVIII в. расселены ойраты-дербеты, которые в этногенетическом отношении являются родственными калмыцким дербетам. Потому калмыцкие инструкторы, среди которых были и калмыки-дербеты, уточняли, когда речь шла о местном дербетском населении. литического просвещения» [Оглаев 1981: 37]. Взаимоотношения с инструкторским составом сложились доверительные, монголы с уважением относились к своим, как они считали, учителям [Монголия в документах 2019: 89]. К августу 1923 г. в различных войсковых частях и военных организациях MHР насчитывалось 76 калмыков, местами их службы являлись Урга, Тамсаг Булаг, Кобдо, Дариганга, Гурван Байн, Солонкер, Замын Уд [С интернациональной миссией 1970: 139-142].

К 1923 г. монгольская армия состояла «из одной бригады двухполкового состава, артдивизион ${ }^{12}$, пулькоманда и военного училища» [Монголия в документах 2019: 17] численность бойцов насчитывала 3132 воинов, из них 1600 - в регулярной армии, остальные в территориальных войсках, на вооружении были «огнеприпасы: 2000000 японских патрон, 1200 трехдюймовых снарядов и одна бронемашина» [Монголия в документах 2019: 17, 18]. В 1924 г. большая часть калмыков, находившихся в Монголии, покинула страну [НА РК. Ф. Р-3. Оп. 10 с. Д. 9-а]. Однако из доклада уполномоченного Коминтерна в Монголии Т. Р. Рыскулова в ИККИ от 2 ноября 1924 г. выясняется, что потребность в инструкторах не отпала, их следовало «обеспечить инструктажем и командным составом», а именно «русско-бурятским элементом». Но, как продолжал Т. Р. Рыскулов, «из бурят составить части невозможно, потому что их набрать почти не из кого, т. е. людей не найдется, а потом монголы к наплыву бурят отнесутся отрицательно» [Монголия в документах 2012: 312-313].

\section{Помощь Монголии калмыкам и про- ект переселения калмыков в Монголию}

Монголия в свою очередь внесла посильную помощь в период голода в Калмыкии в 1921 г. В Урге была создана специальная комиссия по сбору средств голодающим под руководством Ц.-Д. Номинханова (хотя первоначально главой комиссии калмыцкая сторона назначила Вокунаева [Наранжаргал 2014: 51]), в июле 1922 г. был сделан первый финансовый перевод голодающим калмыкам: монгольское правительство разово внесло свыше 4000 руб. за счет процентного отчисления из заработной платы госслужащих. К марту 1923 г. из Монголии

\footnotetext{
12 Так в источнике.
} 
было отправлено 1000 голов скота и 15000 лан серебра [С интернациональной миссией 1970: 23; Оглаев 1973: 35; История Калмыкии 2009: 323; Бадмаева 2010: 174-175; Наранжаргал 2014: 51].

В 1922 г. в правительство Монголии поступила просьба разрешить прибыть в страну членам областного комитета (Калмыцкое представительство) для сбора пожертвований голодающим калмыкам. В январе 1923 г. монгольское правительство выступило с инициативой переселения голодающих калмыков в Монголию с предоставлением им земли, скота и жилищ - юрт ${ }^{13}$. Повторное приглашение было направлено в марте того же года, однако последовал твердый отказ МИДа РСФСР. Находившийся в это же время в Западной Монголии Х. Б. Кануков подготовил свой проект переселения и в Кобдоский округ Монголии части донских калмыков для оказания помощи в землеустроительных работах ${ }^{14}$, при этом прилагался список возможных переселенцев с указанием возраста, места жительства, семейного положения, партийной принадлежности и наличия «специальных знаний» [НА РК. Ф. Р-137. Оп. 1. Д. 4. Л. 200об.].

Разработка Х. Б. Кануковым проекта переселения части донских калмыков в Монголию вызывает недоумение, обращает на себя внимание то, что в проект были включены только донские калмыки-инструкторы. Ведь в 1920 г. именно он воспротивился вхождению сальских (донских) калмыков в состав Калмыцкой автономной области, в которую на основании провозглашенной на I Общекалмыцком съезде советов «Декларации прав трудового калмыцкого народа» должны были войти территории с преимущественным калмыцким населением Астраханской, Ставропольской, Царицынской губерний, Терской и частично Донской областей [Кринко 2019: 790]. Делегат съезда Х. Б. Кануков, следовавший через Элисту в Чилгир, подрался с председателем Манычского улусного исполкома, военкомом и военруком улусного военкомата [История Калмыкии 2009: 279].

\footnotetext{
13 Подробнее см.: [Наранжаргал 2014: 54 $55]$.

${ }^{14}$ В частности, предлагалось создать специальный межевой отдел в министерстве финансов Монголии, организовать курсы для подготовки землеустроителей.
}

Этот «инцидент» не прошел даром: его арестовали на весь период съезда, что впоследствии и вылилось в дальнейшие события. А произошло следующее. Практически через месяц (5 августа) в станице Великокняжеской внезапно был созван I съезд калмыков Сальского округа, в котором приняли участие жители 12 станиц Донобласти (всего 46 делегатов), за исключением Эркетеневской, граждане которой пожелали остаться в составе Автономной области [Кринко 2019: 790].

Инициаторы проведения съезда были ближайшими соратниками Х. Б. Канукова, поэтому никто не сомневался, связывая оба события (съезд в Чилгире и «инцидент» с Кануковым). Решение делегатов не стало неожиданностью: они отказались «входить в административное управление Автономной области Калмыцкого исполкома», оставшись в подчинении Сальского исполкома Донской области», но отдельным калмыкам не возбранялось при желании «выйти из Донобласти в автономную Калмыцкую область» (цит. по: [Кринко 2019: 791]).

Дальнейшие перипетии событий, последовавшие после съезда, не изменили ситуацию: «территория проживания сальских калмыков осталась в составе Донской области» (подробнее см.: [Кринко 2019: 791-795]). Конечно, арест «крупного военного и политического деятеля... по происхождению донского калмыка» в самый ответственный момент провозглашения автономной области и принятого решения Общекалмыцкого съезда объединить разрозненные территории проживания калмыков, неизбрание Х. Б. Канукова в состав облисполкома сыграли существенную роль в «решении выйти из-под контроля Калмыцкого ЦИК», но были и более глубинные причины в потере части территории (подробнее см.: [Кринко 2019: 796]).

Прежде всего, вопрос о вхождении донских калмыков в состав автономии был связан с земельным вопросом. Что могли означать, с одной стороны, проект переселения части донских калмыков в Кобдоский округ Монголии, с другой - демонстративный демарш против решения I Общекалмыцкого съезда об объединении разрозненных калмыцких территорий? Да и по времени эти события очень близки. Парадокс, заглаживание вины или осознание скоропалительных 
решений? Думаю, эти вопросы еще будут в фокусе внимания исследователей. По крайней мере, в список возможных переселенцев в Монголию были включены донские калмыки-инструкторы, первым же числился сам Харти Кануков, 40 лет, о котором автор проекта указал, что он уже проживает в г. Урге, в Монголии, «член Р.К.П с 1918 года», «учитель, военный организатор» [НА РК. Ф. Р-137. Оп. 1. Д. 4. Л. 200об.]. По сведениям Н. Наранжаргала, монгольское правительство предложило переселить 70 семей калмыков [Наранжаргал 2014: 54].

\section{Совместные экспедиции в Тибет}

Вероятно, не будет преувеличением сказать о развитии двусторонних взаимоотношений в свете совместных экспедиций калмыков и монголов в Тибет. Вопрос об экспедиции в Тибет ${ }^{15}$ обсуждался в НКИД осенью 1920 г. [Монголия в документах 2012: 58]. Наряду с другими в обсуждении приняли участие монголы X. Чойбалсан, Д. Сухэ-Батор, С. Данзан и Д. Бодоо, буряты А. Доржиев, Э.-Д. Ринчино и калмык А. Амур-Санан. Перед участниками «небольшой секретно-рекогносцировочной экспедиции» ставилась задача установить связь между РСФСР и Тибетом, провести сбор информации о стране и подготовить почву для будущих официальных переговоров между советским и тибетским правительствами. На экспедицию было выделено 6200 руб. серебром, 200 аршин парчи, четыре винтовки-карабина и автоматическое ружье Шоша для охраны. По результатам экспедиции один из его членов должен был добраться до Афганистана и по радио сообщить итоги поездки в Наркоминдел [Монголия в документах 2012: 59]. Проработка детальной инструкции была возложена на А. Доржиева и Э.-Д. Ринчино, а также на акад. Ф. И. Щербатского [Андреев 2006: 231]. Ее возглавил один из военных инструкторов кавалерийской бригады МНРА донской калмык В. А. Хомутников (псевдоним - Санджи Кикеев); кроме него в состав вошли шестеро калмыков и один бурят. В выборе Хомутникова главой экспедиции

15 Тибет рассматривался как траектория движения мировой революции на Восток. Экспедицию планировалось снарядить в Урге, в ее состав включить калмыков и бурят в качестве паломников [Андреев 2006: 229, 230]. не последнюю роль сыграло то, что при Далай-ламе личным секретарем состоял донской калмык Шарап Тепкин, впоследствии ставший Ламой калмыцкого народа [Бакаева 1997: 9-17; Бакаева 2001: 213-324].

Из Урги отряд выступил в сентябре 1921 г. и достиг Лхасы 9 апреля 1922 г. Аудиенция с Далай-ламой XIII состоялась в Потале, переводчиком выступил Ш. Тепкин. Экспедиция покинула Лхасу 1 мая 1922 г. В отчете, поданном в НКИД, Хомутников подробно проинформировал о политической и хозяйственной жизни Тибета, политических взглядах Далай-ламы и некоторых членов тибетского правительства, отношениях Тибета с Китаем и Англией. В Москве с одобрением приняли отчет Хомутникова об экспедиции, результатом которой стало «восстановление отношений между Россией и Тибетом», и наградили его в 1925 г. орденом Красного Знамени [Выдающийся сын 2012; Бембеев 1991; Убушаев, Надбитов 2015: 122-125].

В 1927 г. Хомутников возвратился в Монголию, возглавил кавалерийскую школу МНРА, а затем продолжил работу в Джаргаланте инструктором 4-го Отдельного кавполка, в 1929 г. он покинул Монголию [Выдающийся сын 2012: 10].

Следующую экспедицию («дипломатическая миссия») в Тибет возглавил заместитель уполномоченного НКИД в Монголии С. С. Борисов (в экспедиции фигурировал под псевдонимом Цэрэндоржи), в нее входили также калмыки и буряты. Главной задачей ставилось «установление двустороннего соглашения и борьба против английской экспансии» [Андреев 2006: 253]. Среди прочих вопросов, Борисову предстояло обсудить возможность отправки в Тибет военных инструкторов-калмыков и бурят, если «тибетское правительство возьмет на себя расходы по их проезду и проживанию» [Андреев 2006: 259].

Группа Борисова выехала из Урги в конце января 1924 г., в Лхасу добралась в августе 1924 г., встреча с Далай-ламой состоялась на следующий день по приезде. В Тибете группа Борисова пробыла около трех месяцев и в мае 1925 г. вернулась в Москву. Переговоры Борисова ни к чему не привели, соглашение между странами не было подписано (подробнее см.: [Андреев 2006: 263, 264, 268]). 
В 1926 г. в Тибет вновь снаряжается советско-монгольская миссия («неофициальное представительство СССР под видом представительства МНР») во главе с калмыком А. Ч. Чапчаевым (формально в должности советника при монгольском после), в состав вошли восемь человек, среди них сотрудники МИД МНР Гомбодчийн и секретарь Амуланг ${ }^{16}$ и лама Гэндэнсодном, бурятский лама в качестве переводчика и два калмыка, бывшие инструкторы МНРА - Мацак Бимбаев и Шагдыр Лундуков [Андреев 2006: 287, 288]. Миссия отбыла в октябре 1926 г. и прибыла в Лхасу в мае 1927 г. Далай-лама выяснил, что прибыла не паломническая группа из Монголии, а «красные монголы», что сразу же осложнило положение миссии, А. Ч. Чапчаев в течение практически пяти месяцев безуспешно пытался добиться аудиенции Далай-ламы, и только в октябре 1927 г. встреча состоялась [Андреев 2006: 291]. Результаты беседы оказались провальными для монгольской и советской сторон: Далай-лама отказался от дипломатического обмена представителями и не проявил внимания к заключению дружественного договора между Тибетом и Монголией, что и являлось главной целью миссии. Единственное, чего добился А. Ч. Чапчаев, - это согласие на торговые («неофициальные») операции СССР в Тибете [Андреев 2006: 293]. За время пребывания в Лхасе М. Бимбаеву удалось собрать сведения о тибетской армии, ее вооруже-

${ }^{16}$ Имеются в виду Гомбо-Идшин Л. — чиновник МИД Монголии, Амгалан - управделами МИД Монголии. Помимо других задач миссии, монголы имели особые поручения своего правительства: «установить дружественные отношения между Монголией и Тибетом, провести религиозные обряды по случаю кончины Богдо Джебцзундамбы у Далай-ламы, ...получить официальное благословение Далай-ламы по вопросу выявления следующей реинкарнации Богдо», скончавшегося в 1924 г. [Батсайхан 2018: 357]. Выявление реинкарнации Богдо-гэгэна VIII действительно входило в планы монгольских посланников, об этом свидетельствует информация ламы Гэндэнсоднома: «...будучи озабочен судьбой своего Богдо Джебцзундамба-хутухты, обращался к видному перерожденцу красной секты Санджи-Панчену с просьбой указать вновь переродившегося Богдо» [Монголия в документах 2019: 166]. нии, побывал он и на учебных стрельбах, привез много фотографий [Андреев 2006: 299]. Монгольские посланники представили монгольскому правительству и ЦК МНРП свой отчет относительно выяснения реинкарнации Богдо-гэгэна [Батсайхан 2018: 359-361].

Отдельного внимания заслуживают сведения торгового представителя Тибета Няньдигла (Нандигла) ${ }^{17}$ в Монголии, зафиксированные в информационном сообщении ОГПУ Бурят-Монгольской республики от 11 ноября 1929 г., где он характеризует главу советско-монгольской миссии А. Чапчаева: «я много помогал ему [Чапчаеву. $K$.O.] в Лхасе при свидании с высшими чинами и самим Далай-ламой, но вскоре я на опыте убедился, что во время обратного следования по пути в Монголию, что он нехороший человек, не может держать себя при дипломатических и прочих разговорах. Человек весьма нервно настроенный, злой, в нем отсутствует минимальная доля добродушия, весьма с большим сомнением, упрямый и жестокий на словах. .... вы все время не ладили с Чапчаевым и его спутниками. По-моему, он человек недостаточно образованный и главное, недостаточно воспитанный. Думаю, что он мог бы быть хорошим слугой в доме, а не вести дипломатическую работу. Будучи в Лхасе, Чапчаев ругался с секретарем Далай-ламы за то, что тот не ускоряет дела свидания с Далай-ламой. Вообще он старался не подчиняться законам страны, которые, кстати, писались действительно не по характеру Чапчаева. ... Частенько выпивая, Чапчаев говорил совершенно безответственные слова тибетцам в Лхасе (какие именно безответствен. слова, Няньдигла уклонился сказать)» [Монголия в документах 2019: 222, 223]. Нелицеприятная оценка и характеристика главы миссии вполне объяснимы. Вероятно, А. Ч. Чапчаев, удрученный провалом миссии, позволил себе неадекватное поведение. Однако, будучи восточным человеком (не говорю о

${ }^{17}$ В течение 15 лет работал торговым представителем Далай-ламы в Монголии, в 1927 г. вернулся в Монголию с делегацией Чапчаева [Монголия в документах 2019: 222]. По сведениям А. Андреева, по возвращении из Лхасы в Улан-Батор М. Бимбаев получил от Няньдигла данные о тибетских оружейных заводах [Андреев 2006: 299, 300]. 
его религиозной составляющей, он считал себя атеистом), вряд ли А. Ч. Чапчаев позволил столь недостойно, как описывается в информационном сообщении, вести себя на почитаемой буддистами священной земле, осознавая, сколько глаз и ушей наблюдают за ним, а главное - понимая необходимость во что бы то ни стало выполнить задание советского правительства. Смею предположить, что имели место личностные взаимоотношения.

\section{Заключение}

Сотрудничество Калмыкии и Монголии в 1920-х гг. свидетельствует о динамичном развитии отношений в рамках военной и гуманитарной помощи. Калмыки-инструкторы в конечном счете выполнили свою

\section{Источники}

НА РК - Национальный архив Республики Калмыкия

Монголия в документах 2019 - Монголия в документах из архивов ФСБ России (19221936 гг.) / науч. ред. В. В. Наумкин, отв. ред. К. В. Орлова, В. В. Грайворонский. М.: ИВ PAH, 2019. 528 c.

Монголия в документах 2012 - Монголия в документах Коминтерна (1919-1934). Ч. I (1919-1929) / науч. ред. Б. В. Базаров. Улан-Удэ: Изд-во БНЦ СО РАН, 2012. 527 с.

Российско-монгольское 2019 - Российско-монгольское военное сотрудничество (19111946): сб. док. Ч. І. М.: Граница, 2019. 359 с.

\section{Литература}

Андреев 2006 - Андреев А. И. Тибет в политике царской, советской и постсоветской России. СПб.: Изд-во С.-Петерб. ун-та; Изд-во А. Терентьева «Нартанг», 2006. 464 с.

Бадмаева 2010 - Бадмаева Е. Н. Нижнее Поволжье: опыт и итоги реализации государственной политики в социально-экономической сфере (1921-1933 гг.). Элиста: НПП «Джангар», 2010. 544 с.

Бакаева 1997 - Бакаева Э. П. Лувсан Шараб Тепкин и его время // Шамбала. 1997. № 5-6. C. 9-17.

Бакаева 2001 - Бакаева Э. П. Глава калмыцкой церкви (шаджин-лама): процедура избрания // Российское монголоведение. Бюллетень V. М.: ИВ РАН, 2001. С. 213-324.

Бакаева 2019 - Бакаева Э. П. Этническая идентичность калмыков и конфессиональные задачу, хотя бы на первых порах привести монгольскую армию в относительно боеспособное состояние, монголы же протянули руку помощи в тяжелый для калмыков период голода. Включение в составы экспедиций в Тибет в 1920-гг. калмыков и бурят (две экспедиции возглавляли калмыки) также свидетельствует о понимании советским руководством значимости религиозной и этнической принадлежности сотрудников миссий. Дополнительные материалы показали также, что при выстраивании отношений руководство калмыков и монголов прежде всего исходило из родственных связей между народами, языковой и культурной общности. Немаловажную роль имела религиозная идентичность.

\section{Sources}

National Archive of the Republic of Kalmykia.

Bazarov B. V. (ed.) Mongolia in Documents of the Comintern: 1919-1934. Vol. I: 1919-1929. Ulan-Ude: Buryat Scientific Center (Sib. Branch) of RAS, 2012. 527 p. (In Russ.)

Kudryavtsev I. I. et al. (comps.) Russia-Mongolia Military Cooperation: 1911-1946. Collected Documents. Vol. I. Moscow: Granitsa, 2019. 359 p. (In Russ.)

Naumkin V. V., Orlova K. V., Graivoronsky V. V. (eds.) Federal Security Service Archives: Mongolia Documented, 1922-1936. Moscow: Institute of Oriental Studies (RAS), 2019. 528 p. (In Russ.)

связи с Тибетом (к прочтению малоизвестных источников) // Oriental Studies. 2019. № 5. C. 891-925. DOI: 10.22162/2619-09902019-45-5-891-925

Батсайхан 2018 - Батсайхан О. Последний великий хан Монголии Богдо Джебцзундамба-хутухта VIII. Жизнь и легенды. М.: Товво научных изданий КМК, 2018. 406 с.

Батунаев 2016 - Батунаев Э. В. Монголия: от революции 1921 г. до провозглашения независимости // Власть. 2016. № 7. С. 183-186.

Бембеев 1991 - Бембеев В. Ш. Человек из легенды. Элиста: Издат. центр «Контекст», 1991. $187 \mathrm{c.}$

Бимбаев 1981 - Бимбаев М. Т. Дорогой братства // Теегин герл. 1981. № 4. С. 59-65.

Выдающийся сын 2012 - Выдающийся сын калмыцкого народа. Элиста: Герел, 2012. $23 \mathrm{c}$. 
История Калмыкии 2009 - История Калмыкии с древнейших времен до наших дней. Т. II. Элиста: Герел, 2009. 840 с.

История Монголии 2007 - История Монголии. ХХ век. М.: ИВ РАН, 2007. 448 с.

Кринко 2019 - Кринко Е. Ф. Сальский инцидент, или О том, как донские калмыки не вошли в состав Автономной области трудового калмыцкого народа // Oriental Studies. 2019. № 5. C. 787-798. DOI: $10.22162 / 2619$ 0990-2019-45-5-787-798

Курас 2016 - Курас Л. В. Транснациональная история монгольского мира в условиях революционного подъема: первая четверть XX века / рук. проекта, отв. ред. Б. В. Базаров, науч. ред. М. Н. Балдано. Иркутск: Оттиск, 2016. 252 c.

Лузянин 2000 - Лузянин С. Г. Россия - Монголия - Китай в первой половине ХХ в. Политические взаимоотношения в 1911-1946 гг. М.: ИДВ РАН, 2000. 268 с.

Наранжаргал 2014 - Наранжаргал Н. 1920нод оны Ижил мөрний сав дагуух өлсгөлөн ба халимагуудыг Могол улсад нүүлгэн шилжүүлэх гэсэн асуудлын тухай (= О голоде в Поволжье в 1920-х гг. и о переселении калмыков в Монголию) // Вестник Калмыцкого института гуманитарных исследований РАН. 2014. № 3. С. 50-56.

Наранжаргал 2015 - Наранжаргал Н. Новые источники о первой монгольской делегации в СССР // Вестник Калмыцкого института гуманитарных исследований РАН. 2015. № 2. С. 31-34.

Оглаев 1970 - Оглаев Ю. О. Введение // С интернациональной миссией. Воспоминания

\section{References}

A Prominent Kalmyk (V. Khomutnikov, 18911945). Elista: Gerel, 2012. 23 p. (In Russ.)

Andreyev A.I. Russia and Tibet: A History of Tsarist, Soviet and Post-Soviet Policy. St. Petersburg: St. Petersburg State University, Narthang, 2006. 464 p. (In Russ.)

Badmaeva E. N. Lower Volga Region, 1921-1933: Experience and Results of the Government's Socioeconomic Policy. Elista: Dzhangar, 2010. 544 p. (In Russ.)

Bakaeva E. P. Ethnic identity of the Kalmyks and confessional ties with Tibet: a case study of some little-known sources. Oriental Studies. 2019. No. 5. Pp. 891-925. (In Russ.) DOI: 10.22162/2619-0990-2019-45-5-891-925 участников монгольской народной революции / под общей ред. И. Я. Златкина, сост. Ю. О. Оглаев. Элиста: Калм. кн. изд-во, 1970. C. 6-28.

Оглаев 1973 - Оглаев Ю. О. Двадцать семь месяцев в народной Монголии (май 1921 - август 1923 гг.) // Церен-Дорджи Номинханов. Филологические вести. 1973. № 4. С. 30-36.

Оглаев 1981 - Оглаев Ю. О. На земле братской Монголии // В бою - в одном экипаже, в труде - в одной бригаде. Элиста: Калм. кн. издво, 1981. С. 33-44.

Рощин 1999 - Рощчин С. К. Политическая история Монголии (1921-1940 гг.). М.: ИВ РАН, 1999. 327 с.

С интернациональной миссией 1970 - С интернациональной миссией. Воспоминания участников монгольской народной революции. Под общей ред. И. Я. Златкина, сост. Ю. О. Оглаев. Элиста: Калм. кн. изд-во, 1970. 142 с.

Убушаев, Надбитов 2015 - Убушаев В. Б., Надбитов М. В. Спецкомандировка героя Гражданской войны в России Василия Хомутникова в Тибет к Далай-ламе XIII // Историческая и социально-образовательная мысль. 2015. Т. 7. № 6 (2). C. 122-125. DOI: 10.17748/2075-9908-2015-7-6/2-122-125

Хишигт 2011 - Хишигт Н. Восстановление независимости Монголии в 1911-1921 гг. // Вестник Бурятского научного центра Сибирского отделения РАН. 2011. № 3. С. 1935.

Ширендыб 1971 - Ширендыб Б. История Монгольской народной революции 1921 г. Сокр. пер. с монг. яз. М.: ГРВЛ, 1971. 398 с.

Bakaeva E. P. Head of the Kalmyk Church (Shajin Lama): election procedures. In: Mongolian Studies in Russia. Vol. V. Moscow: Institute of Oriental Studies (RAS), 2001. Pp. 213-324. (In Russ.)

Bakaeva E. P. Luvsan Sharab Tepkin and his time. Shambhala. 1997. No. 5-6. Pp. 9-17. (In Russ.)

Batsaikhan O. $8^{\text {th }}$ Jebtsundamba Khutukhtu: The Last Great Khan of Mongolia. Life and Legends. Moscow: KMK Science Publ., 2018. 406 p. (In Russ.)

Batunaev E. V. Mongolia: from the Revolution of 1921 till independence. The Authority. 2016. No. 7. Pp. 183-186. (In Russ.)

Bembeev V. Sh. The Man of Legends. Elista: Kontekst, 1991. 187 p. (In Russ.)

Bimbaev M. T. Following the path of brotherhood. 
Teegin gerl. 1981. No. 4. Pp. 59-65. (In Russ.)

Khishigt N. Restoring the independence of Mongolia: 1911-1921. Bulletin of the Buryat Scientific Center of the Siberian Branch of the Russian Academy of Sciences. 2011. No. 3. Pp. 19-35. (In Russ.)

Krinko E. F. The Salsk Incident: or how Autonomous Oblast of the Kalmyk Working People was never joined by the Don Kalmyks. Oriental Studies. 2019. No. 5. Pp. 787-798. (In Russ.) DOI: 10.22162/2619-0990-201945-5-787-798

Kuras L. V. Transnational History of the Mongolian World in the Revolutionary Upsurge: 1900s-1920s. B. Bazarov, M. Baldano (eds.). Irkutsk: Ottisk, 2016. 252 p. (In Russ.)

Luzyanin S. G. Russia-Mongolia-China Relations in the Early-to-Mid-20 ${ }^{\text {th }}$ Century: Political Affairs, 1911-1946. Moscow: Institute of Far eastern Studies (RAS), 2000. 268 p. (In Russ.)

Maksimov K. N. et al. (eds.) History of Kalmykia: from Earliest Times to the Present Days. In 3 vols. Vol. II. Elista: Gerel, 2009. 840 p. (In Russ.)

Naranjargal N. New sources on the first Mongolian delegation in the USSR. Bulletin of the Kalmyk Institute for Humanities of the RAS (Oriental Studies). 2015. No. 2. Pp. 31-34. (In Russ.)

Naranjargal N. On the famine in the Volga Region in the1920s and on the issue of the Kalmyks' resettlement to Mongolia. Bulletin of the Kalmyk Institute for Humanities of the RAS (Oriental Studies). 2014. No. 3. Pp. 50-56. (In Mong.)
Oglaev Yu. O. Introduction. In: Zlatkin I. Ya. (ed.), Oglaev Yu. O. (comp.) For the International Cause: Mongolian Revolution of 1921, Memoirs of Immediate Participants. Elista: Kalmyk Book Publ., 1970. Pp. 6-28. (In Russ.)

Oglaev Yu. O. On the land of brotherly Mongolia. In: Oglaev Yu. O. Together in Combat and Labor. Elista: Kalmyk Book Publ., 1981. Pp. 33-44. (In Russ.)

Oglaev Yu. O. Twenty seven months in the Mongolian People's Republic: May 1921 August 1923. Tseren-Dordzhi Nominkhanov. Filologicheskie vesti. 1973. No. 4. Pp. 30-36. (In Russ.)

Roshchin S. K. Political History of Mongolia: 1921-1940. Moscow: Institute of Oriental Studies (RAS), 1999. 327 p. (In Russ.)

Shirendev B. Mongolian Revolution of 1921: A History. Moscow: GRVL, 1971. 398 p. (In Russ.)

Ubushaev V. B., Nadbitov M. V. Special mission of the hero of the Civil War in Russia Vasily Khomutnikov in Tibet to Dalai Lama XIII. Historical and Social-Educational Idea. 2015. Vol. 7. No. 6 (2). Pp. 122-125. (In Russ.) DOI: 10.17748/2075-9908-2015-7-6/2-122-125

Yaskina G. S. (ed.) History of Mongolia: $20^{\text {th }}$ Century. Moscow: Institute of Oriental Studies (RAS), 2007. 448 p. (In Russ.)

Zlatkin I. Ya. (ed.), Oglaev Yu. O. (comp.) For the International Cause: Mongolian Revolution of 1921, Memoirs of Immediate Participants. Elista: Kalmyk Book Publ., 1970. 142 p. (In Russ.) 